\title{
LA GUAJIRA: \\ MÚSICA DE SOLISTAS EN TIERRA DE SOLEDAD
}

José PeÑín

\section{Resumen}

Los indígenas wayúu, conocidos comúnmente como "guajiros", habitan la Península de la Guajira compartida actualmente por Colombia y Venezuela. Es una de las etnias latinoamericanas que mantienen con mayor vigencia sus tradiciones. En el presente trabajo se hace un recorrido por su hábitat y estructura social, con especial reposo en sus manifestaciones musicales.

\section{Abstract}

The "wayúu" aboriginal tribe, better known as "guajiros", lives at the Guajira peninsula which is shared nowadays by Colombia and Venezuela. They are one of the Latin American ethnic group that keeps its traditions as they used to be centuries ago. This paper shows not only the "wayúu" social structure and environment, but it especially studies this indigenous group's music.

\section{El sitio}

Allí por donde empieza la cabeza de la América del Sur, en la Península de la Guajira, sobre una extensión de más de $15.380 \mathrm{~km}^{2}$, un $20 \%$ hoy territorio venezolano y un $80 \%$ de Colombia, sobre una tierra semiárida donde el viento fresco del norte impide la lluvia frecuente, con vista al mar Caribe sembrado de bellas islas como los Monjes cercanos, desde tiempos imprecisos viven los "guajiros", autodenominados en su propia lengua como wayúu: gente, pueblo, habitante. Son gentes de filiación lingüística arawako para algunos autores y para otros caribe.

Al norte, en la Alta Guajira, sobre un piso arenizo, una vegetación xerófila, ("maleza desértica tropical") salpica aquí y allá el paisaje árido en extremo. Pueden verse médanos de arena como los de Tapurí. La sombra difusa del cují o "trupillo" (prosopis juliflora), no es suficiente para albergarse de un sol justiciero la mayor parte del año. El cactus abundante y altivo es el mejor símbolo de esta tierra recia y agresiva en su monotonía. El cují, fuente de alimentación, tanto en sus hojas como en sus vainas, guarda, cuando el animal las ingiere, el agua que necesita. Mientras, al sur, en la Baja Guajira, las tierras mejoran relativamente. Con algo de agua para riego, un clima más benéfico y algunos pastizales para la ganadería, ofrece otras posibilidades económicas. Mejora la ilusión del vivir. En 
general, son tierras planas arenosas con algunas serranías en la parte central de la península que pueden alcanzar una altura de 700 u 800 metros sobre el nivel del mar.

Las lluvias son intensas y abruptas en la Guajira durante los meses de septiembre a noviembre, el resto del año es de sequía, por lo que el guajiro solamente siembra en la época de lluvia. Este fenómeno se da también en otras partes del área del Caribe como en los llanos, que por la escasez de agua prácticamente sólo se trabaja la agricultura en el período lluvioso. Según algunos autores, en otros tiempos lejanos, la situación de la Guajira no presentaba el estado actual de aridez y sequía. Las lluvias tenían lugar con una cierta regularidad, produciendo un estado general de la vegetación distinta con posibilidades agrícolas que hoy no tiene.

El agua es, definitivamente, el problema endémico para el habitante actual de estas tierras. La propaganda en las campañas electorales ${ }^{1}$ ha sido reiteradamente el ofrecimiento de solucionar este problema, pero sin embargo, pasan los gobiernos y esta necesidad sigue allí. Pozos (ya con bombas o molinos de viento), lagunas y jagüeyes es la esperanza de todo guajiro. Los pozos construidos por el gobierno son de utilidad pública. Pero los puede haber privados. Los lugares con agua propician un cierto sendentarismo. Y es que el guajiro no es propiamente nómada, pero sí un pueblo de gran movilidad por el pastoreo, que por la preferencia por los lugares con agua y por la necesidad de encontrar trabajo, emigra hacia las ciudades importantes tanto de Colombia (Rioacha o Maicao) como venezolanas (Maracaibo, por ejemplo). Son andariegos, por el contrabando, por el comercio, por la búsqueda de trabajo en las grandes y prósperas haciendas, sobre todo en el sur del Lago. No son nómadas "per se", pero sí dados al desplazamiento frecuente. Al contrario de lo que viene sucediendo con otros grupos indígenas americanos con una marcada tendencia a disminuir en número o incluso a desaparecer, en el caso de los guajiros se han mantenido en cantidad e incluso han crecido relativamente, debido a su sólida estructuración como grupo humano.

La cantidad de habitantes varía mucho dependiendo si se tiene en cuenta solamente los residentes en La Guajira propiamente dicha o los guajiros por raza e idioma que deambulan lejos de su tierra. En total se estima entre los 100.000 y 200.000 wayúu de acuerdo a la fuente. Y es que en realidad no tenemos censos fiables. De ellos, un $40 \%$ viven dispersos más allá de la Península de la Guajira. En la Guajira, habitan fundamentalmente indígenas guajiros y en muy poca cantidad "alijunas", o sea, criollos o habitantes no wayúu. El guajiro convive con el criollo en ciudades como Rioacha y Maicao en Colombia, así como Paraguaipoa y El Moján en la parte venezolana. Tierras adentro, en cambio, es muy raro encontrarse con algún alijuna.

Sobre su origen pende la gran incógnita de cualquier cultura ágrafa. Los primeros testimonios que tenemos son los del cronista Juan de Castellanos, cuando a comienzos del siglo XVI pasa por esta zona y habla de la existencia allí de unos "indios feroces" conocidos como "cocinas" o "cosinas". Ya otro de los cronistas importantes del siglo XVI como es Fray Pedro Simón, los identifica con el término guajiro, así como también hace referencia a la existencia de algún tipo de ganado introducido por los españoles. Los europeos tuvieron un asentamiento para extracción de perlas en

1. Asistimos a una campaña electoral municipal mientras hacíamos la investigación, y los candidatos se esforzaban en recorrer la Península con camiones cisternas poniendo paños calientes a la escasez de agua y por el tiempo de campaña. 
Cabo de La Vela durante los primeros días de la Colonia, hoy en territorio colombiano, el cual desaparece a comienzos del siglo XVII. Según Perrin (1980: 245), para mediados del siglo XVI ya los guajiros se habían convertido en un pueblo ganadero. A mediados del siglo XVII los franciscanos capuchinos fundan misiones en la zona, incluyendo Sinamaica en territorio hoy venezolano. Las misiones aceleran la incorporación de nuevos recursos de producción agrícola y ganadera. En forma particular caprino y ovino. El cabrito termina por ser hasta el día de hoy el centro de su producción económica y de su dieta alimentaria (carne y leche de cabra como tal, y quesos) a la vez que lo incorpora como elemento central de su vida cultural. Sin embargo, el éxito de las misiones fue relativo. La resistencia wayúu y la misma configuración geográfica de la Península, abierta al mar, sirvió para aliarse comercialmente con piratas y corsarios. Fueron los indígenas wayúu los que suministraron ganado con frecuencia a estos grupos que merodeaban por El Caribe en contra de la corona española, protegidos por los gobiernos de Inglaterra, Holanda y Francia para debilitar el poderío español en la zona. Algunos autores dicen que facilitaron durante la guerra de los Siete Años unas 600 cabezas de ganado a la flota inglesa en el Caribe (Kuethe, 1970: 469). Esta situación llevó por parte del poderío español a construir misiones fortificadas y emprender una actitud dura para dominar a los guajiros. El dominio relativo de la población guajira se da en el siglo XX tanto por el gobierno venezolano como por el colombiano. Y aunque hay presencia militar allí, sin embargo, sigue siendo hasta el día de hoy más formal que efectiva. Por ejemplo, desde Paraguaipoa hasta Castilletes, en la parte venezolana, en unos ciento y pico kilómetros, apenas había el año 1976 cuando hicimos allí nuestra investigación ${ }^{2}$, un cuartel de la Guardia Nacional con cinco efectivos asignados, de los cuales solamente en la noche quedaban dos guardias, el que había hecho el servicio durante el día y el que venía a reemplazarlo; a la vez que también había un piquete de unos 15 soldados en el extremo de la Península, en Castilletes. Durante todas las semanas que pasamos recorriendo la Alta Guajira, nos movimos con total libertad a uno y otro lado de la frontera (las demarcaciones no estaban visibles) y ni una sola vez nos encontramos con una patrulla del ejército colombiano o venezolano. Las fuerzas armadas mantenían una actitud permisiva y de muy poco control, probablemente para no entrar en conflicto con las grandes mafias guajiras e internacionales del contrabando, una de las maneras más exitosas del "desarrollo" de la zona. Esta práctica, muy utilizada ya desde la Colonia, ha seguido hasta el día de hoy y ha fortalecido algunos clanes que han consolidado la estructura social de los mismos indígenas guajiros, blindando las posibilidades de instalación de otros grupos humanos en la zona. Todavía hoy, la presencia del criollo es muy baja en el área. Particularmente la Alta Guajira, está casi sólo habitada por wayúu.

Parecería que el indígena wayúu actual asimiló a su tradición a partir de la Colonia, una fuerte influencia pastoril en torno a nuevos animales incorporados a su proceso económico como es el chivo. Los instrumentos actuales guajiros, los clarinetes como el totoroyoi o maasi, por ejemplo, tienen evidentes similitudes con un ancestro cultural pastoril de otras culturas como las arábigas del Cuerno Africano del norte de ese continente. Curiosamente la misma vestimenta talar

2. Habíamos trabajado el año 1974 en la Baja Guajira colombiana. 
actual de la mujer guajira (parece que antiguamente llevaban el torso desnudo) denota fuertes similitudes con el África arábiga, así como también la importancia del tío materno en la organización social, entre otros aspectos que en algún momento habrá que estudiar. Esto presenta grandes interrogantes. ¿Recibieron esta influencia vía España? ¿Hubo algún contacto directo? o ¿Ha sido creación propia ante circunstancias ambientales similares? Ante esta realidad, más de un autor ha señalado estas coincidencias. Sin embargo, no se tiene documentación que pueda aclarar una relación directa o indirecta con el mundo árabe desértico del norte africano. Y lo que otros autores señalan que lo recibieron a través de España, tampoco se ha podido establecer, cuando incluso en la misma España no tenemos testimonios de los instrumentos arriba señalados, por ejemplo, o comportamiento social similar al wayúu. Lo curioso de todo esto es que su economía, mitología y vida social, giran hoy alrededor del chivo, una incorporación a la cultura wayúu evidentemente producto de la llegada del europeo al continente americano y que le da un nuevo sentido a su vivir hasta el día de hoy. Esta nueva modalidad va a implicar una adaptación de su cultura en general en torno a este recurso de producción, hasta tal punto que se presentan hoy como un grupo indoamericano con características únicas. Vale señalar que la incorporación de este tipo de animales en otras partes de América del Sur, como sucedió con la oveja en la Patagonia argentina, el manejo del patrón económico derivado de la producción ovina no quedó en manos de los indígenas sino del criollo. Finalmente, la cuestión que se plantea a partir de esta realidad es que no sabemos a ciencia cierta cuáles fueron las características reales de los antiguos habitantes de la Península de la Guajira antes de la llegada del europeo. En todo caso, su configuración actual dista mucho de otros grupos indígenas americanos que mantienen ciertos rasgos que nos retrotraen a procesos etnohistóricos anteriores a la llegada del europeo, aspecto que no está tan claro en la cultura guajira actual.

La vivienda ("piichi” en la Alta Guajira y "miichi” en la Baja) es a dos aguas o con una sola caída, rectangulares o casi cuadradas, con techo de palma ("yotojolo") y paredes de "bahareque" a la manera tradicional, mientras que hoy ya una buena parte se hacen con techos de láminas de zinc, de bloques, piso y paredes de cemento. Cerca de la vivienda está la enramada ("luma") que es un sitio central y común de la ranchería donde se conversa, se descansa en los "chinchorros", se hacen negocios o se recibe a los visitantes. El lugar para cocinar está cerca de la vivienda protegida con cerca de troncos de madera de cují (común a todas las cercas). En la ranchería también suele haber un espacio con tres paredes donde colocan los telares y un poco más allá, un corral para los animales hecho de estacas de un metro y algo. La agrupación de varias viviendas se conoce como "máima píichi" (muchas casas) con habitantes unidos por consanguinidad matrilineal o uterina. A este tipo de complejo habitacional hasta los mismo wayúu hoy lo conocen como ranchería.

Los hombres visten a la manera criolla si salen de su hábitat, mientras que allí, cuando trabajan o descansan, llevan el torso desnudo, con sombrero de fibra de paja o maguey, alpargatas tejidas con suela de cuero o goma y amarradas con trenzas al tobillo, así como "wayuco" o taparrabo. En cambio las mujeres, antes con el torso también desnudo, desde hace ya mucho tiempo utilizan la manta guajira de vistosos colores, con mangas cortas o largas, que las cubre desde el cuello hasta los 
pies moldeando elegantemente la esbeltez de su cuerpo con gran vuelo y soltura. También utilizan alpargatas con vistosas borlas normalmente tejidas. Adornan su cabeza con llamativos pañolones y sus cuellos con piedras pulidas de jade ("tu'uma") de color ocre, negro o rojizo, un tipo de cornalina que se encuentra en las tumbas de la vecina Sierra Nevada de Santa Marta de los antiguos taironas, antecesores de los actuales indígenas Kogi y Aruacos. Antiguamente, tanto hombres como mujeres se pintaban la cara de diferentes colores (negro, rojo o azul oscuro) sacados de sustancias vegetales, carbón, frutos, hongos, etc. En general, el colorante vegetal se conoce como "parisa" o "bija". Hoy solamente se pintan con motivo de alguna fiesta, viaje o celebración social. En estos casos, los hombres pueden utilizar vestimenta especial. Se arropan también con vistosas mantas de colores y colocan sobre la cabeza el "carrektse" (un penacho coronado con una larga pluma) o con menos frecuencia el "tooloma", una especie de abundante peluca esférica.

La hamaca, utensilio de gran utilidad expandido en forma ancestral entre las comunidades indígenas del área caribeña (también hoy de uso normal para el criollo), tanto de tejido cerrado como abierto (conocido en este caso como "chinchorro"), la cuelga el guajiro en la enramada o dentro de su rancho para el sueño, el amor y el descanso.

La movilización antes se hacía en burro o a caballo. Todavía se ve de vez en cuando, especialmente cuando se recogen fondos para pagar alguna deuda por deshonor, jinetes guajiros en cansinas bestias recorriendo el monótono paisaje en cumplimiento de su causa. Sin embargo, hoy, La Guajira, es un cruce permanente de marcas que dejan con abundancia los cientos de automóviles, especialmente camiones y pick-up, que recorren las arenizas tierras en todas la direcciones. Una carretera levantada sobre la extensa planicie guajira para evitar en época de lluvias los bajos inundados, va, por ejemplo, desde Los Filuos hasta Castilletes en territorio venezolano, asomándose de vez en cuando a la costa. Su estado era tan malo cuando la conocimos, que para los guajiros o algún visitante accidental que llegaba por allí, era preferible seguir alguna de las muchas huellas que otros carros hicieron sorteando la vegetación xerófila, fáciles para perderse en un paisaje árido y siempre parecido asimismo, que esquivar lo huecos de aquella supuesta carretera. En todo caso, este infinito número de marcas y huellas que dejan pequeños camiones, siempre llenos de wayúus parados sobre su plataforma de carga, llama la atención al visitante. En la quietud de paisaje, con frecuencia se ven estos medios de movilización, muchas de las veces en caravanas de tres o cuatro, que se desplazan sin que en apariencia se vea a qué lugar, pues lo que predomina en la zona es la soledad. Parecería que esos muchos caminos son atajos laberínticos que se enredan sobre sí mismos para no llegar a ningún lugar.

El guajiro se acuesta temprano y se levanta al amanecer. Tienen la costumbre que cuando van a hacer alguna diligencia, generalmente esperan hasta el día siguiente. En su camino van dando las informaciones a los que se encuentran del sitio de donde vienen como un largo sendero de hormigas. Así las noticias corren por la Península de la Guajira con cierta rapidez, donde la soledad del silencio parecería no decir nada.

Los extremos de la temperatura van desde los $14^{\circ}$ hasta los $40^{\circ}$, siempre amortiguada por una brisa pertinaz y refrescante, particularmente cuando uno está bajo una enramada o a la sombra de algún arbusto que terminó por imponer su mayoría a la agresividad del lugar. 

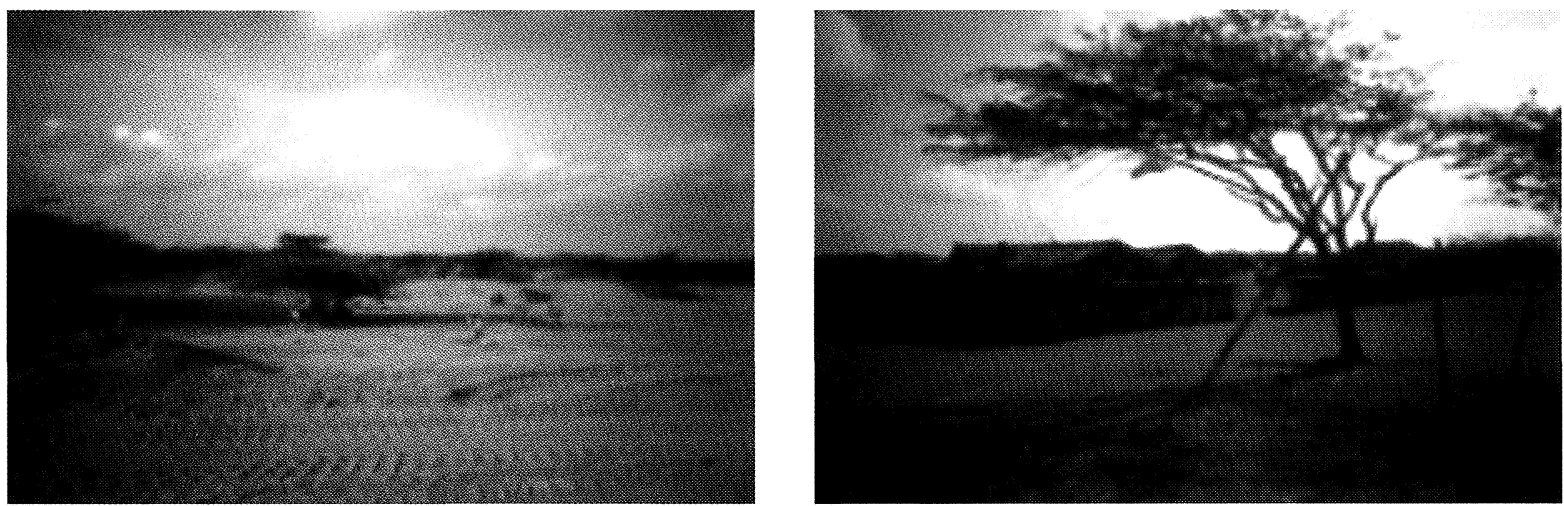

\section{La estructura social}

Los guajiros se organizan por clanes o "sibs". El clan se reconoce por un animal o por el territorio al que pertenezcan ${ }^{3}$. Cada clan tiene inclusive su marca para señalar el ganado. Como dice Wilbert (1972: 175): "la tribu se divide en una treintena de castas, cada una de las cuales tiene su propio territorio y se identifica con un animal". La casta Uriana, por ejemplo, tiene el tigre, muy común en Paraguaipoa; los Jarariyu se identifican con el perro y pertenecen a la casta Fernández; los Ipuana tienen el águila, etc. Sin embargo, hoy la gran mayoría de los clanes o sibs están dispersos tanto en la Península de la Guajira como fuera. La sociedad guajira se organiza y articula en una compleja red de subgrupos sociales. Como en otros muchos aspectos de la sociedad guajira, también en éste es muy variada su estructura. No hay una sola manera de organizarse. Los autores o investigadores sociales del wayúu hablan de la familia nuclear, la familia matrilocal, el matrilinaje mínimo, el matrilinaje máximo y el sib matrilineal, etc. Estamos ante un grupo humano que mantiene unas grandes líneas de acción y organización, pero con gran relatividad en la implantación de las mismas. No hay duda que la mujer juega un papel predominante y es que la cultura guajira gira alrededor del concepto uterino. A través de la procreación, los hombres pasan su sangre a los hijos y las mujeres su carne. Son más sólidos los lazos de carne que de sangre. Wilbert (1970: 309) puntualiza: "Mientras que la carne continua existiendo indefinidamente en el tiempo, generando su propia sangre específica, la sangre del padre disminuye a través de la generaciones hasta llegar a desaparecer". Por eso, "el padre goajiro carece de toda autoridad legal sobre los hijos y no tiene obligaciones legales permanentes para con ellos" (Wilbert, 1970: 317). Watson (1967: 11) llega a afirmar que "el padre no es un verdadero pariente, aunque reconoce plenamente su relación especial para con el hijo".

Las diferencias sociales entre los guajiros es también notoria. Aunque predominan los pobres, sin embargo, por diferentes vías desde los negocios legales hasta el contrabando, algunos clanes han logrado un poderío económico que mantienen por tradición. Hoy también, hay ya un número impor-

3. Ver: MATOS ROMERO, Manuel. La guajira su importancia. Caracas: Empresas el Cojo, 1971, pp.129-137 donde detalla una larga lista de nombres y lugares. 
tante de indígenas guajiros que han alcanzado un grado de instrucción universitario y con ello también su estatus social ha variado, incluso llegando a tener poder político y económico en la estructura general del país en organismos públicos venezolanos y colombianos. Este fenómeno ha tenido lugar particularmente en la parte venezolana, donde la proximidad de la Universidad del Zulia ha brindado a los guajiros la posibilidad de acceder a sus aulas desde hace ya varias décadas.

Los hombres hacen los trabajos de siembra, caza (antes con flecha y hoy con una gran variedad de armas de fuego que les posibilita la intensa actividad contrabandística en la zona) y pesca, mientras que la mujer se encarga de los deberes de la casa. El pastoreo puede ser compartido, en buena parte bajo la responsabilidad de niños y niñas. En los trabajos de artesanía, la cerámica (de carácter utilitario) está a cargo de la mujer, mientras que la tapicería la pueden trabajar hombres y mujeres. En las últimas décadas los tapices han alcanzado un nivel artístico comercial con trascendencia nacional. En los años setenta del siglo pasado se pusieron de moda los tapices tejidos en los talleres de Luis Montiel y Rina. Muchas oficinas y salones privados de las principales ciudades del país fueron decorados con estas vistosas obras artesanales. En el tapiz pueden verse en forma abstracta dibujadas las diferentes partes del chivo como los cuernos, el corazón, el intestino, el rabo etc., así como también es una constante la colocación en ellos de rosetones o simplemente el sol en el centro del tapiz.

El cuero, que podría ser otro de los elementos artesanales, lo usan solamente con una finalidad utilitaria, ya sea para el calzado u objetos de monturas de bestias. Su manejo se hace en forma rudimentaria, sin mayores técnicas de curtido, sino simplemente secándolo al sol con el "si'ichi", un arbusto rico en tanino.

Otra de las ocupaciones hoy, muy frecuente en el guajiro pobre, está en el trabajo de peón en las haciendas del sur del Lago de Maracaibo dedicados al cultivo del plátano ${ }^{4}$ o cría de ganado. No obstante, la ocupación más extendida en su propio hábitat es el pastoreo. Donde hay un animal, siempre habrá un guajiro que lo cuida, normalmente escondido, agazapado entre la maleza, bien para protegerse del sol inclemente, como para no ser sorprendido.

Cuando la mujer llega a la pubertad, se la aísla de los hombres, se la encierra por un tiempo en un cuarto o en una construcción hecha especialmente para ello e incluso se le puede dar una purga para salir de la infancia. Se le corta el cabello y es instruida particularmente por las mujeres adultas de su familia en las obligaciones de mujer. El aislamiento puede llegar a durar entre dos y cinco años, dependiendo del estatus de la familia. Puede estar los primeros días colgada en una hamaca cerca del techo. El fin del "blanqueo" se celebra con el baile, la "yonna", y un baño. Luego está lista para el matrimonio. No hay una ceremonia especial para ello. En primer lugar, se procede al trámite de la dote. Se entrega el precio de la novia a su familia generalmente en cabras, ovejas y otros animales, aunque hoy ya también en dinero, bebidas, prendas, etc. El wayúu le da mucha importancia a la virginidad, por lo que puede ser devuelta una novia si no cumple con este requisito. El hombre puede tener tantas mujeres cuantas pueda sostener y pagar, mientras que la mujer está sujeta a su matrimonio por lo menos hasta llegar a la menopausia, cuando adquiere mayor libertad.

4. En Venezuela se conoce como plátano un tipo de banano grande muy utilizado para acompañar los platos tradicionales tanto indígenas como de la cocina criolla. Se usa tanto frito como cocido. 
Es momento de alegría para el núcleo familiar el nacimiento de una niña, porque con ello va implícito, en el momento del casamiento, la dote y por lo tanto el aumento del patrimonio familiar. Aunque en realidad no es propiamente un concepto de dote, sino más bien de depósito, pues si la mujer no cumple con el código tradicional guajiro, la familia está obligada a devolver lo que se le entregó.

Son también parcialmente polígamos. Cuando un hombre tiene varias esposas, normalmente vive con una regularmente y visita las otras periódicamente. Vimos en nuestro viaje cómo en las rancherías hay tantas viviendas como mujeres en posibilidad de gestación. De hecho nuestro guía, cuando visitamos una ranchería en el Cerro de la Teta en la parte colombiana, decidió quedarse allí un fin de semana mientras nosotros regresamos a Cojoro donde teníamos nuestro punto de residencia en el cuartel de la Guardia Nacional y donde él también tenía su mujer principal. Luego nos enteramos que se quedó allí porque tenía otra mujer en aquella ranchería. En principio, la ley guajira le permite al hombre tener tantas mujeres como pueda sostener. Aunque esto también es muy relativo, pues hoy por las leyes colombianas y venezolanas, legalmente no es permitida la poligamia. Sin embargo, en la práctica esto siempre es muy elástico incluso en el mundo criollo. Según Watson (1967:33): "el pagar por la novia, le otorga al hombre el derecho al acceso sexual de la mujer de un modo excluyente, además de otros derechos. Si la esposa es infiel, ella y su familia deben devolver toda la dote".

También practican el levirato. Los hermanos y los sobrinos de un hombre en edad postpubescente, tienen el derecho a pretender en matrimonio a su viuda. Ellos decidirán quien será el nuevo esposo con las obligaciones de criar sus hijos. Si la viuda está en una edad postmenopáusica es libre para decidir lo que quiera, pero tendrá que devolver parte del precio de la novia a los hermanos o sobrinos de su esposo difunto. Las mujeres pobres se casan más temprano porque las familias piden menor dote, mientras que las más ricas demoran más su soltería debido a este asunto. En todo caso se respeta a la mujer. La mujer puede caminar por las largas soledades de la Península de la Guajira sin el peligro de que la vayan a agredir.

La comida tiene como centro el chivo y la bebida tradicional son la chicha fermentada (chicha de Castilla le dicen todavía hoy en algunos lugares de América) y el "chirrinchi", un aguardiente o caña blanca destilada en viejos y clandestinos alambiques, de viejas y peligrosas tuberías de cobre a la usanza de los días de la colonia. Es éste un antiguo recurso de origen español. Un sistema de producción prohibida por sus riesgos sanitarios, por lo que solamente la pudimos ver en lugares retirados y en forma escasa. La bebida alcohólica es uno de los problemas de salud pública entre ellos. También el wayúu es un beodo incorregible hoy, a lo que contribuye la facilidad que tiene para lograr a través del contrabando una gran variedad de bebidas alcohólicas occidentales como whisky, cerveza, ron, etc.

Todo lo que tiene que ver con la muerte y el más allá, juega un papel importante en la cultura guajira. Al difunto lo envuelven en una sábana o sudario de tela o cuero, le ponen sal, colocan al lado del cadáver comida y bebida y hasta le dan un trago de aguardiente para el largo viaje que deberá realizar. Después de unos meses, cuando el cuerpo se descompone, recogen los huesos, los limpian y practican el segundo entierro definitivo en el lugar correspondiente al clan o familia. En los dos entie-

rros se realiza el velorio. Se pasan el día acompañando al difunto mientras las mujeres preparan la comida, las plañideras o lloronas profesionales en largas cantilaciones recuerdan las virtudes y accio- 
nes del difunto, mientras los hombres se entretienen bebiendo y haciendo alarde de su habilidad en el arte del tiro con modernas armas de fuego.

\section{La ley guajira}

El Dr. Manuel Matos Romero 5 , abogado, estudió profusamente este aspecto como también otros de la cultura wayúu, especialmente en su libro Derecho civil y penal guajiro. El "Pupchipu” o abogado guajiro. Aquí se hace un "estudio sobre el derecho oral o tradicional guajiro y la función que desempeña el "Pupchipú" o abogado dentro de la comunidad indígena".

Un principio muy destacado y a veces llevado a extremos tan violentos donde se transgrede los principios fundamentales de los derechos humanos, es la aplicación de la justicia por sus propias manos una vez agotada la intervención de un intermediario o "palabrero". Las agresiones se pagan en dinero o en animales, si no la venganza puede llegar a situaciones dramáticas, pues por generaciones se siguen cobrando estas deudas. El deudor debe pagar y si no lo hace él, tendrá que hacerlo su familia. Son históricas las peleas por generaciones entre clanes, que han llegado, en circunstancias, prácticamente hasta la aniquilación, especialmente por problemas de deshonor. La función de palabrero ("pútchpala") o mediador entre las partes, se reserva a los hombres. Hoy también ejercen esta función personeros de los gobiernos colombiano o venezolano. El guajiro tiene un exagerado sentido de la justicia, especialmente si se ha pedido algo en pago.

La propiedad privada de armas, ganado y herramientas, determina el estatus del guajiro. En cambio, la tenencia de la tierra es de uso comunitario, como suele suceder en las comunidades indígenas americanas en general. Sin embargo, ya, sobre todo en la Baja Guajira, hay extensiones de terreno cercadas. Es más, algunas familias guajiras poderosas, son dueñas hoy de haciendas especialmente al sur del Lago de Maracaibo donde la actividad agropecuaria es de alta intensidad y calidad. La convivencia con el criollo y el sometimiento a principios de gobernabilidad occidentales impuestos por los gobiernos colombiano y venezolano en manos de los criollos, hace que esta conducta social también se imponga entre los wayúu. Aunque la cultura indígena guajira se ha resistido a la influencia criolla occidental, sin embargo, hay aspectos en los que finalmente termina cediendo. Su estado de rebeldía y cohesión interna, han permitido que todavía hoy conserven vigentes antiguas estructuras culturales y sea un grupo étnico con poca permeabilidad. Llama poderosamente la atención cómo fueron fuertemente penetrados en un primer momento con la llegada del europeo, y sin embargo, posteriormente han mantenido una férrea resistencia a dejarse penetrar por el mundo criollo. No obstante, en la práctica, el mismo devenir histórico se ha encargado de ir penetrándolos sutilmente con formas y recursos propios de la cultura occidental globalizada como son el transporte, los medios de comunicación, alimentación, salud, etc. Los wayúu no se escapan a lo que está pasando en líneas generales con el mayor número de culturas indígenas americanas. El problema que se plantea es entre

5. Nosotros lo entrevistamos el año 1976 antes de adentrarnos en La Guajira y fuimos gratamente sorprendidos por su amplio conocimiento de la cultura wayúu. 
dejar estos grupos étnicos a su libre desenvolvimiento o incorporarlos a las nuevas tecnologías. Una disyuntiva con aristas positivas y negativas de difícil solución.

La autoridad se ejerce también en forma variada. En principio no hay una línea o estructura ni vertical ni democratizada de este ejercicio. Hubo, no tanto hoy, períodos donde figuras especiales por su liderazgo derivado de la fuerza moral o de su poder económico (hay que tener presente que para el guajiro la riqueza es señal de poder), o por una combinación de ambos, existieron algunos personajes tan destacadas que se los reconoció como caciques o "alaula". Hay también ancianos, reconocidos por su prestigio, que ejercen fundamentalmente una autoridad moral o de gran consejero para un grupo más o menos amplio de la comunidad. En todo caso, no hay una autoridad suprema que tenga o ocupe un rango que cubra toda la raza guajira, ni desde el punto de vista local o regional. En la tradición guajira relativamente cercana, se recuerdan algunos nombres que por su autoridad moral, riqueza, valentía y cumplimiento de la ley guajira han sido calificados como caciques; así: Eleuterio Paz, Bartolo González "El Asao", José de los Santos "El Cuya", el cacique y piachi "El Mama", Luis Fernández "El Chioco", Eleuterio Paz "Yhajaira", José de la Rosa Fernández "El Torito", Lisandro Fernández "El Payara”, Rafael González "El Maneto", Uriana Manuel González "Guarero”, etc. A pesar de todo esto, no hay una estructura de mando fija. El liderazgo informal generalmente lo ostentan hombres mayores respetables. No hay caciques que se elijan, ni tampoco se hereda esta categoría, no tiene verdaderos gobernantes. Cada clan o comunidad tiene un jefe que suele ser el más rico entre ellos y en el ámbito familiar el tío mayor por línea materna. Más bien los caciques surgieron por las relaciones políticas y económicas con los alijuna. Hoy, sin embargo, se está imponiendo cada vez más, el concepto de liderazgo tanto por la actividad política como social o preparación profesional dentro de la misma comunidad. En el día a día familiar, ocupa un lugar especial de mando el tío mayor del grupo, aunque es la mujer la que decide fundamentalmente el quehacer diario.

Vale destacar que aunque la estructura social guajira es predominantemente uterina, donde la mujer juega un papel más importante que el hombre, sin embargo, a la hora de heredar solamente estos lo pueden hacer (Romero:1975: 81).

\section{Cosmogonía: el gran sueño}

Sus mitos están expresados en su narrativa. Michel Perrin recolectó cerca de 400 mitos diferentes. Maleiwa es el creador, demiurgo, héroe cultural. Juya es el ser hipermasculino y Pulowi el hiperfemenino. Juya vive más allá del sol, es guerrero, seductor y progenitor; es andariego, explica la movilidad guajira. Juya es lluvia, Pulowi es la esposa de Juya. Pulowi no es andariega y vive bajo la tierra en las profundidades del mar. No tiene forma fija. Pulowi significa la estación seca, el hambre, la hostilidad. Según M. Perrin ninguno de los dos son objeto de ninguna plegaria, ni culto especial, ni se les rinde sacrificios.

6. Vivió cerca del cerro Macuire y tuvo el privilegio de hacer suya toda joven guajira de su clan antes de casarse. La cercanía de los guajiros con los grupos indígenas de la Sierra Nevada, Kogí y Aruakos, los ha llevado a tener algunas influencias de ellos como esta denominación "Mama", jefe supremo de los Kogí o el uso de "tuumas" para los collares. 
Las almas de los animales que se sacrifican en los funerales se reúnen con el difunto en la tierra de los muertos, esto es el Jepirra o Jepira, donde los muertos gozan del mismo estatus social que aquí en la tierra. Jepirra es la tierra de los muertos ("yolujaa") donde los fallecidos deambulan "como una segunda imagen del alma". El guajiro cree en la inmortalidad del alma. Los bienes del difunto deben gastarse en su velorio para que su memoria sea honrada debidamente. La carne de los animales sacrificados se la reparten entre los asistentes fuera de la familia, pues de lo contrario sería como comerse la misma carne del pariente difunto y apropiarse de ellos en forma utilitaria. El simbolismo de la muerte del animal y mancharse las manos con sangre tiene el poder de destruir el mal o alimentarlo. La sangre tiene un elemento misterioso ("a'alania"). En el Jepirra las mujeres se vuelven sexualmente agresivas y son ellas las que buscan al hombre y pueden tener los que deseen. Se invierten los papeles. El espíritu de los muertos se puede convertir en maligno, esto es, en "wanulü".

El contacto con el más allá se hace a través de los "piache" (wanülu) o chamanes. La mayoría de los chamanes son mujeres casadas. Ellas se contaminan en sus contactos con el mundo de los muertos, por eso, para no morir, tienen que mascar "manilla" (tabaco) al invocar los espíritus. El piache vaticina el futuro viendo el humo del tabaco quién es su contacto con los wanulü. El contacto con la muerte enferma, por eso hay que bañarse con chirrinche, una bebida profiláctica. La piache se encierra en un lugar y en su soledad no permite la presencia de nadie que pueda ver los ritos del caso. En nuestra investigación tuvimos la oportunidad de consultarle a una piache por el futuro de nuestro viaje. La piache se encerró en un rancho, mientras nosotros quedamos afuera. Un "cajero", también desde afuera, hizo diferentes toques informando del acto que se estaba realizando hasta largas leguas, mientras que dentro se escuchaba ininterrumpidamente la piache con exclamaciones, cantos y sonidos extraños acompasados con una maraca. Al final salió y nos dijo que nuestro viaje iba a terminar felizmente como sucedió. Previamente tuvimos que pagarle la sesión.

Si alguien en un sueño es premonitoriado su destino como piache, la familia debe buscar algún piache que lo inicie. La iniciación consiste en enseñarle a tocar la maraca y los cantos apropiados para cada espíritu. Este aprendizaje se hace en sesiones secretas lejos de las miradas de asistentes curiosos. Después de unos cuarenta días, la iniciada (en algunos casos puede ser también varón) está lista para cumplir las funciones de piache o chamán. El maestro o maestra es la que decide cuándo el alumno tiene las habilidades requeridas para reconocer las enfermedades, ponerse en contacto con el más allá y prever el futuro. Como en todos los actos importantes en la vida guajira, el proceso termina con una celebración o baile al que se invita a través de toques especiales de casha y a la que asistirán jóvenes vírgenes ("majayuras"). Después de la celebración la nueva piache está lista para ejercer su oficio. Roberto Pineda Giraldo describe así un acto de curación por una piache:

Mientras se realiza la ceremonia, el piache mastica continuamente el tabaco y con la mezcla producida por la saliva y el jugo de la planta, fricciona todo el cuerpo del paciente y, acto seguido, chupa fuertemente, por varias veces consecutivas las partes afectadas del enfermo, para sacarle el mal humor.

Las canciones que entona el piache van refiriendo como su espíritu anda buscando el alma del enfermo que el espíritu de la enfermedad y de la muerte se ha llevado a regiones desconocidas que sólo

7. Ejecutante de la casha o tambor guajiro. 
aquel y el mismo piache conocen. Muchas veces el espíritu del enfermo no se deja coger por piache, o sucede que su alma está prisionera, encarcelada por obra y gracia de los wanurü, lo que acarrea un trabajo bastante fuerte al piache. Cuando esto se logra, por intermedio de su espíritu protector la conquista del alma del enfermo, debe pagar al wanurü que lo tenía prisionero un rescate por la liberación ${ }^{8}$.

Cuando el piache logra su objetivo, rocía al enfermo con sal para que el mal espíritu no regrese. Cada parte del proceso de curación lleva toques especiales de casha que lo van anunciando. Si el enfermo cura se hace una fiesta y por supuesto con el baile de "la Yonna" o de la chicha maya.

Para el wayúu son muy importantes los sueños. "Son considerados como revelaciones del porvenir, provenientes de un espíritu benigno que quiere manifestar de esa manera su protección a un individuo determinado" (Pineda, 1950:47). Dependiendo del status de la persona que lo tiene, el sueño será más importante. Si el sueño es de un chamán, es muy importante para tenerse en cuenta. Hay que cumplir sus instrucciones, pues el no cumplir los designios del sueño trae muchas desgracias e inconvenientes.

Sin embargo, sus creencias no implican un ceremonial especial, ni templos, ni estructura religiosa alguna. No hay lugares ni castas sociales entre ellos dedicados al culto. No tienen liturgia. Hay manifestaciones con baile y sacrificio de animales para celebrar el primer aguacero importante u otras finalidades, pero esto es simplemente celebración sin implicaciones religiosas, así como otras costumbres de iniciación en el caso de la mujer, matrimonio o funerarios, pero no un ritual litúrgico establecido.

El ídolo de oro "Walhlaj" en el formato masculino y femenino lo sacan o exhiben cada cuatro años. Para las familias que lo poseen, que son muy pocas, es señal de alto linaje. El "Walhlaj" lo guardan en una lujosa mochila de hilo colgada en el techo del rancho.

Utilizan también la "Lania" o "contra", un talismán que sirve para amparar a la persona de sus enemigos presentes y ausentes. Es una madera pequeña en forma cónica del tamaño de la uña de un dedo.

Vale señalar antes de entrar directamente en los aspectos musicales propiamente dichos, que la comunidad guajira mantiene hasta el día de hoy una fuerte coherencia cultural como grupo, y a pesar de la necesidad de incorporarse a las estructuras nacionales, es quizás la única de las comunidades indígenas nacionales que han sabido balancear la conservación de sus costumbres y el aprovechamiento de bienes y valores de la sociedad nacional criolla. De hecho, como ya señalamos, están jugando en los últimos años un papel destacado en la política y en la vida profesional en general. Por la proximidad con la Universidad del Zulia un grupo significativo de guajiros han egresado ya de una variada gama de carreras. Llama la atención cómo tanto los profesionales guajiros como el indígena aislado en formas de vida ancestrales, actúan seguros de sus propios valores culturales, apegados a la tradición de sus ancestros y están haciendo el máximo esfuerzo por mantenerlos. Les toca vivir en un área fronteriza de enormes riesgos y sus actividades comerciales dependen de las circunstancias del momento. En estos últimos años, por ejemplo, muchos se dedican al contrabando de gasolina porque les favorece el precio, mucho más caro en Colombia que en Venezuela.

8. PINEDA G., Roberto, 1947:19.

9. Amuleto o brebaje para contrarrestar la acción maléfica. 
Evidentemente hay un cierto desgaste o cambio en algunas manifestaciones musicales que entran en la evolución de cualquier proceso cultural. Ya hoy conseguir buenos ejecutantes de totoroyoi o del taliray resulta difícil. Sufren los embates de cambio comunes a la cultura tradicional oral en general. Nos atrevemos, sin embargo, a decir que en el caso de los guajiros, por su coherencia cultural, los procesos de cambio son lentos a pesar de la fuerte penetración de los medios y el mercado. Hoy tenemos una Guajira muy parecida a la Guajira de hace treinta años atrás.

\section{La soledad del sonido}

La música en el guajiro cumple una función absolutamente social como suele suceder en toda cultura ágrafa. Su música es primordialmente usada para el pastoreo con bifuncionalidad. Sirve por un lado para entretener, consumir las largas horas aburridas del pastor y por el otro, para manejar, conducir o manipular el rebaño con cantos, gritos y toques instrumentales. El animal (chivos y cabras casi con exclusividad) identifica a su dueño por el modo de tocar, gritar o cantar. Mucha de la música guajira es hecha en soledad, por despecho, por aburrimiento, por intimidad, al que invita la soledad del paisaje. Es música para solistas hecha por solistas. Música para el desamparo, para la aridez de una tierra seca. No hacen música en conjuntos instrumentales o vocales. Y cuando hacen música en función social, en grupo, es con la participación de uno o varios cantantes, pero siempre en forma sucesiva o alternada y nunca a la vez. Es música monódica. La presencia de oyentes es simplemente para aseverar la pertinencia de los cantos o jayeechi. Simplemente para aseverar si lo que el cantante solista está diciendo vale la pena escucharlo o no. Lo mismo sucede con las plañideras en los actos funerarios al recordar las acciones en vida del difunto, también lo hacen en forma solista. Ni siquiera utilizan instrumentos musicales armónicos. Sus clarinetes, flauta u ocarina (predominan entre ellos ostensiblemente los aerófonos), el taliray (un cordófono), la maraca y el birimbao (idiófonos) o la kasha (membranófono), son instrumentos para el decir melódico de sonidos sucesivos, nunca simultáneos. Es una cultura musical para el sonido sólo del solista, en extensa tierra de árida soledad.

Sus músicas, tanto las cantadas como instrumentales, llevan el sello de la improvisación, o más bien, de la creación inmediata. Hasta los textos son relatos que en un momento dado o por una determinada circunstancia, un cantante solista va improvisando y recibiendo la anuencia, la aprobación de los asistentes, si lo hace dentro de los cánones de su tradición. Este aspecto de la creación inmediata es tan importante en la cultura guajira, que el registro tanto en grabación como pautado, nunca reflejará exactamente un contenido fiel y estable. Cada hecho musical es simplemente el testimonio referencial a un estilo de hacer música, a una manera de cantar o tocar. Pero nunca, un fonograma con un contenido fijo y estable, inamovible, siempre igual y con valor en sí mismo, permanente en su tradición. Por esta razón, en la cultura guajira podemos hablar de estilo musical, pero no de un corpus sonoro fijo. Y es que cada creación inmediata será distinta, llevará la carga de la novedad, aunque deba estar sujeta a los patrones de estilo y temática que los códigos culturales guajiros tradicionales establecen. Por supuesto, que además del estilo o manera de hacer música, conservan ciertos relatos o temas en su bagaje cultural, pero a la hora de implementarlos, cada intérprete dará una versión propia, una versión 
suya, que a su vez será distinta cada vez que la haga de nuevo. En el caso de la grabación, será la mejor manera, la más fiel para recoger estos testimonios musicales. Sin embargo, la transcripción o notación en el sistema musical occidental, además de los problemas que de por sí tiene este tipo de registros al pretender recoger otras músicas con una serie de elementos para los que no tiene simbologías apropiadas y por lo tanto no ser un medio válido para su fijación, al ser una cultura a la que se le añaden estos otros elementos de la creación inmediata, hacen poco fiables y hasta casi inútiles los sistemas de notación musical occidental para este tipo de músicas. El recurrir a ellos y pretender darlos como el reflejo de un determinado testimonio musical, es algo inexacto y hasta poco honesto.

No obstante, hay que señalar algunos rasgos o estilos de la manera de hacer música en la cultura wayúu que se desprenden de la simple audición. Así, por ejemplo, tanto en el canto como en el toque instrumental de los instrumentos de viento, utilizan una sola inspiración para el fraseo, el cual dependerá de la capacidad que tenga el intérprete en la administración de aire, como señalaremos más adelante. Por otra parte, el movimiento melódico se mantiene en general en un ámbito de quinta y se mueve tercamente por grados conjuntos. Las apoyaturas, notas escapadas, arrastres, repercusiones, efectos guturales, etc., son también comunes, como en otras culturas. Es notoria la utilización en el canto de un sonido nasalizado.

\section{Los cantos}

Los cantos guajiros conocidos como jayeechi, cubren toda la gama de temas y circunstancias de la vida del wayúu. Los hay de carácter narrativo, etnohistórico. Los hay para revelar sueños o para contar viejas leyendas o mitos. Los hay para relatar el acontecer vital de personajes importantes. Los hay para ensalzar las grandes hazañas o el carácter de valientes wayúus. Los hay de despecho y galanteo. Los hay para recordar las virtudes de familiares que se fueron. Los hay de entretenimiento para los largos ratos de pastoreo. Los hay para criticar situaciones sociales. En todo caso, siempre los hará un solo cantor que en la mejor de las circunstancias puede alternar con otro y sin acompañamiento instrumental. Son siempre cantos solistas, monofónicos. Nunca polifónicos o heterofónicos. Nunca llevan acompañamiento instrumental.

Pineda Giraldo (1950:126) se refiere a ellos en los siguientes términos:

Encabezado por una especie de juglar o cantador que va narrando los acontecimientos que se desarrollan; el lenguaje empleado es dramático y utiliza los más bellos giros de la lengua; la música verbal se une al drama pero no bajo la forma de masas corales, sino expresada por cada uno de los cabecillas que dirigen la acción de los participantes en la escena que se quiere presentar. Desgraciadamente, estas canciones no se conservan tradicionalmente, sino que son más bien improvisaciones; lo único que perdura es la música, compuesta por algún indígena, especialmente por un habitante de Jarara, que es la cuna de la poesía y de la música...

Los cantos pueden ser ejecutados por hombres y mujeres, aunque hay algunos como los chamánicos que están a cargo generalmente de mujeres, así como los funerarios, donde normalmente los 
hacen plañideras profesionales. No obstante, aunque nosotros sólo vimos mujeres en los velorios a los que asistimos, hay algunos autores que hablan de la posibilidad de que el hombre también se incorpore a estos menesteres de cantos funerarios, pero en este caso tendrá que cubrirse la cara con el sombrero.

El buen cantor lo tiene que hacer con voz gutural, nasalizada y en registro grave, particularmente las mujeres. Catherin Cameron (1973) lo dice así: "este tipo de canto áspero y ronco es un estilo de canto valor". Así como también la frase musical depende de un solo aliento de respiración. El fraseo depende de la capacidad de inspiración y administración de ese aire en la expiración. Por eso a veces cuando no se administra bien el aire y se produce agotamiento respiratorio, terminan en forma brusca la frase tanto en el canto como en la ejecución de sus aerófonos. Éste es uno de los aspectos más interesantes en la técnica wayúu, y es que esta relación entre frase y respiración se aplica por igual al canto y a la ejecución instrumental. Se canta como se toca y se toca como se canta. De la capacidad y manejo del aire en la ejecución, depende en buena parte que la comunidad considere que está ante un buen cantante o un buen instrumentista. Es un parámetro fundamental de valorización colectiva.

La música está al servicio del relato, de la letra, por lo tanto el ritmo será libre, dependiendo del énfasis y puntos acentuales del texto ${ }^{10}$. Y es que el canto jayeechi guajiro siempre está en función social, cantado por un solista y sin acompañamiento instrumental. No tenemos información de ser usado en la danza, solamente para decir mejor un texto.

A la introducción, generalmente a boca chiussa, siempre de carácter lento, sobre un sonido largo donde el cantor utiliza expresiones como "jummm... jummm", "ajá" o "annn...", le sigue el desarrollo del relato. Predomina en el decir de texto un carácter narrativo con fragmentos cantilados. Se encadena una "estrofa" o fragmento literario a otro sin que esté determinado un número fijo de partes ni una forma literaria preestablecida. Hay mucho de improvisación que el público asistente acompañará con expresiones como jumm... jumm o "anasii" en señal de aprobación a lo que está diciendo el cantante tanto en su contenido como en la forma. Los textos del relato en general son largos con una melodía similar ajustada a los cambios y detalles que exija el texto. El cantante termina el relato cantado con un fuerte y seco jumm...aaa y dando las gracias con la expresión anashi a lo que los asistentes contestan en señal de reconocimiento, jumm o anashi también.

Tanto los temas como la forma de hacerlo se trasmite por vía oral. En la enseñanza juega un papel importante el tío mayor materno además de los padres. El desarrollo melódico es descendente con un desenvolvimiento melódico normalmente pentatónico, con cortes bruscos de sonido seco al final de cada período o subperíodo.

10. Cosa curiosa estas coincidencias en técnicas o principios valorativos entre culturas que no tuvieron relación como es el principio de tocar como se canta y cantar como se toca que fue tan importante, por ejemplo, para la interpretación del hot jazz, o la relación entre texto y música tan caro a la cultura occidental desde los griegos a los troveros y trovadores, pasando por el canto gregoriano o el romancero tradicional cantado. 

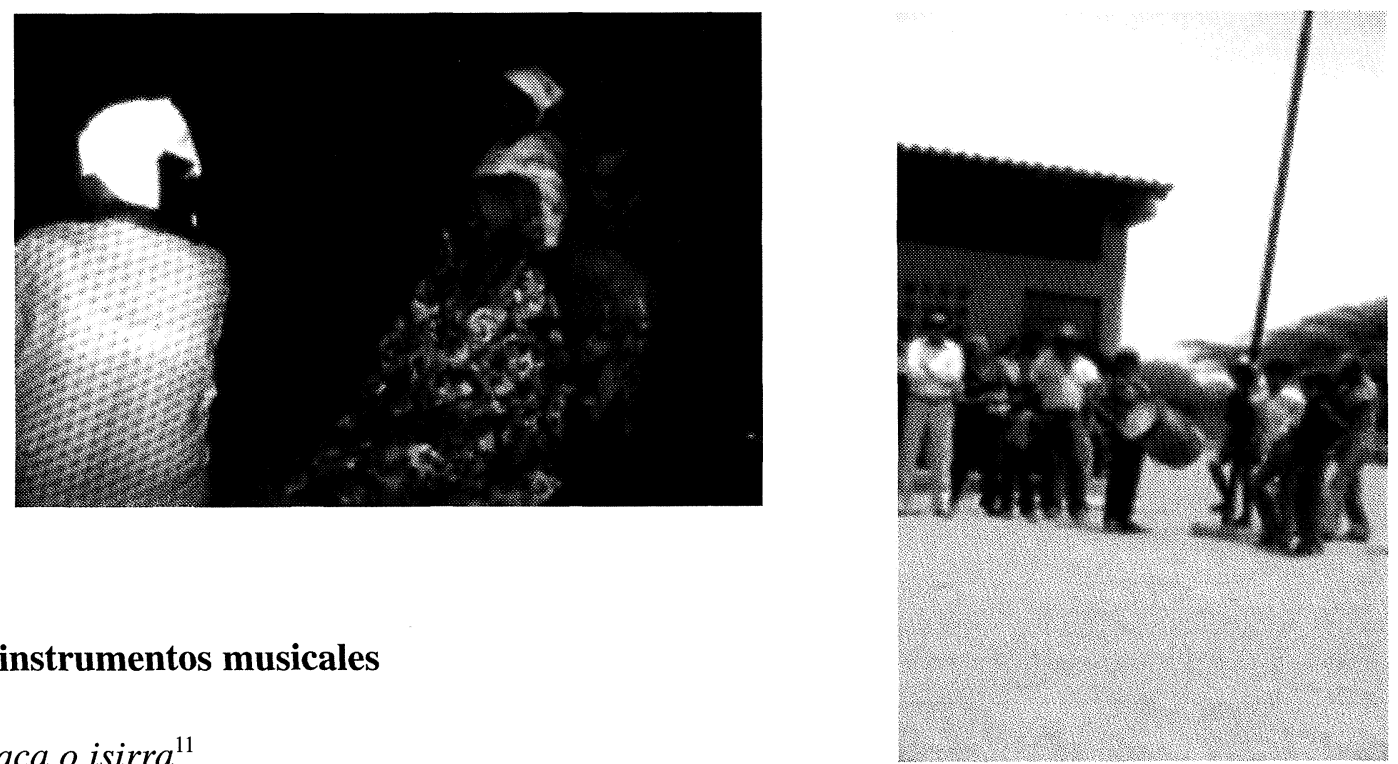

Maraca o isirra ${ }^{11}$

La maraca es un idiófono de golpe indirecto hecho de calabaza seca con semillas en su interior y con un mango. Es utilizada exclusivamente por la mujer piache en sus ritos chamánicos de curación o adivinación del futuro. Cumple una función de acompañamiento rítmico en los cantos ininteligibles de la piache, "aúutsu" o chamán, que junto con el alcohol y el tabaco la llevarán a un estado de trance. Hay que notar que como sucede en otros rituales chamánicos de diferentes grupos étnicos latinoamericanos, la piache usa un solo ejemplar y no el par, como es común en las manifestaciones folklóricas criollas. Además de la maraca, utiliza en estos menesteres sonajas en el empeine, que percuten al golpear el piso con el pie.

\section{Birimbao o trompa guajira}

Estamos ante un idiófono hecho con un marco o armazón de hierro en forma de pera abierto en sus puntas al que se le fija una lengüeta de metal que va sujeta en la parte ovalada más ancha del marco y sobresale un poco por entre la parte angosta con doblez de las puntas abiertas del marco. El ejecutante apoya el marco entre los dientes y con el dedo índice pulsa el extremo libre de la lengüeta, usando la mano y la boca como caja de resonancia. Su sonoridad produce una gama rica en armónicos.

Este instrumento está registrado en Europa ya desde el siglo XII como guimbarda o arpa judía ${ }^{12}$, y fue muy usado en los siglos XIV, XV y XVI en países como Escocia. Pero no sólo en Europa, sino

11. Se puede ver la entrada correspondiente a maraca en la Enciclopedia de la Música en Venezuela, donde Manuel Antonio Ortiz por primera vez no sólo presta la atención necesaria a este instrumento, sino que recoge una visión panorámica del uso extensivo e importancia de este instrumento en la etnomusicología venezolana.

12. Esta denominación es común en inglés (jaw's harp). Para algunos, es una corrupción de jaws harp (arpa de quijadas). 
que prácticamente está en todos los continentes. Es una de esas curiosidades organológicas, que siendo un instrumento no fácil de construir, esté entre pueblos de muy pocos recursos técnicos y en un amplísimo mapa de dispersión entre culturas que no han tenido relación entre ellas.

Llega a América con el proceso de colonización. Además de los guajiros hay otros grupos que con otros nombres lo conservan todavía hoy como sucede con los indios mapuches o matakos en el noroeste argentino. Los wayúu actuales lo tocan para enamorar a la mujer, para los ratos de despecho o descanso bajo la enramada balanceándose en forma acompasada en el chinchorro bajo el cielo abierto antes de dormir. El guajiro imita con este instrumento los sonidos de la naturaleza o de los animales que lo rodean. Es un instrumento intimista de muy corto alcance sonoro.

Con frecuencia se le colocan unas borlas de colores colgados del instrumento simplemente para resguardarlo de su extravío por lo pequeño que es.
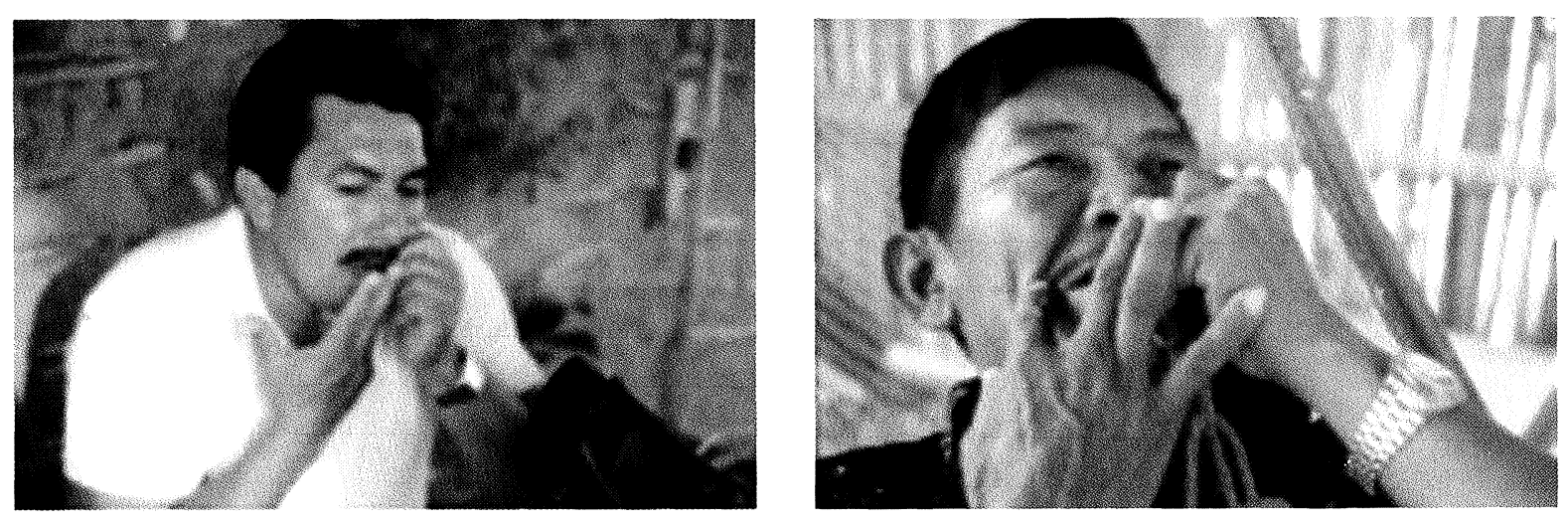

\section{Kasha, Kaashi o Caja, tambor}

La caja guajira es un membranófono de doble parche de piel de chivo colocados en dos aros cilíndricos de madera uno en cada extremo del tambor y amarrados el uno al otro con cuerda o fibra vegetal en forma de $\mathrm{Y}$, tensados en la parte central por ataduras transversales. El instrumento tiene unos $70 \mathrm{~cm}$ de largo y 40 de diámetro. Se ejecuta con dos baquetas o palos, colgado sobre el hombro del ejecutante (generalmente hombre) quedando un poco debajo de la cintura, cómo para percutirlo con comodidad. El parche inferior lleva atravesada una chirlera o bordona a la manera de los redoblantes militares occidentales. Es un instrumento de visible ascendencia europea.

Es el instrumento más usado por el guajiro, particularmente en las danzas como la "yonna" señalando y dando instrucciones a los bailarines de los diferentes momentos del baile. También en

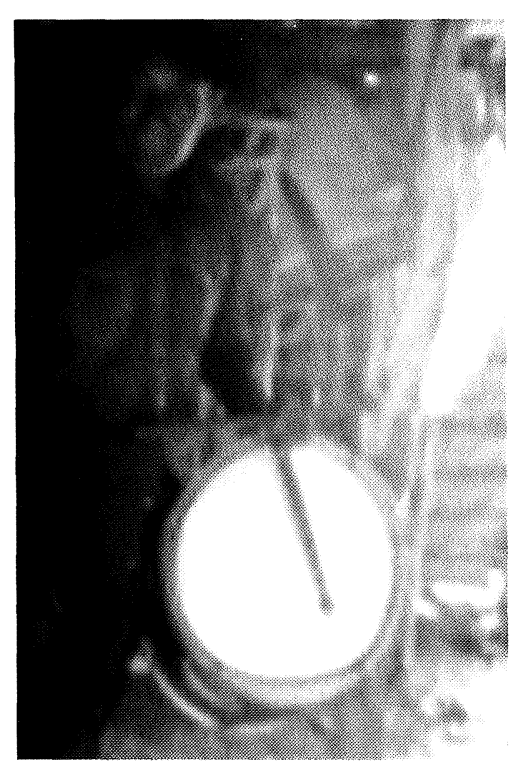


ritos de chamanismo, castración o marca de animales, comunicación de señales o para la carrera de caballos con golpes de arranque, triunfo del jinete o finalización del evento, etc.
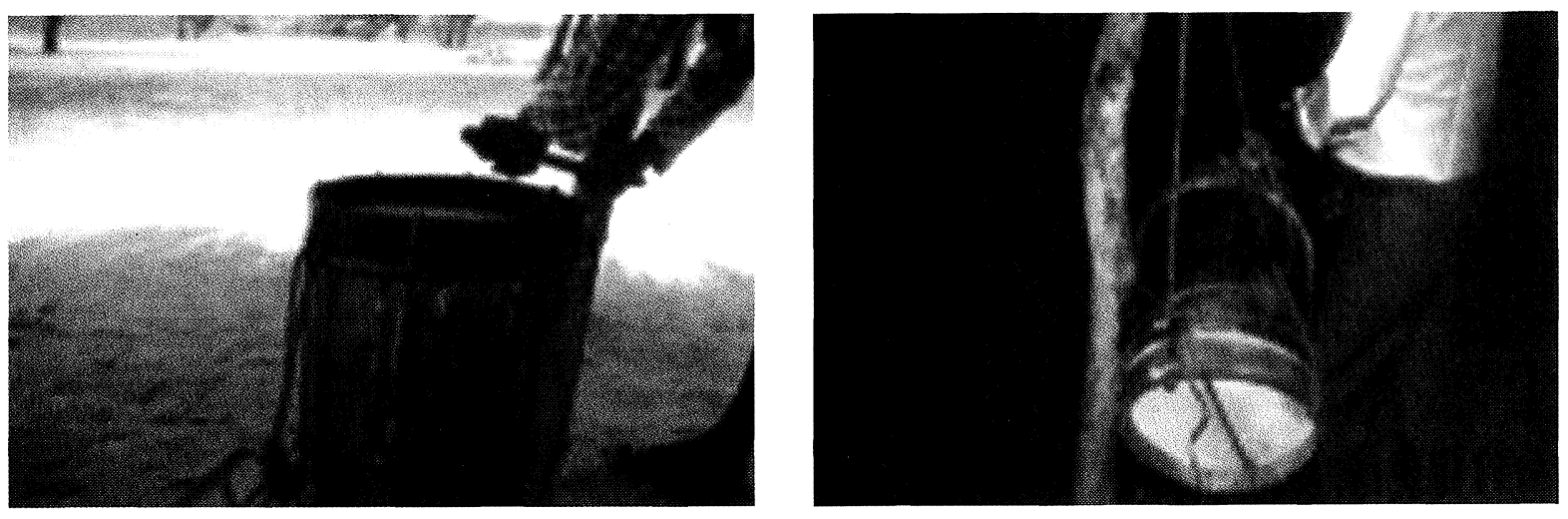

Wa'wai

Es un aerófono hecho de calabaza o "taparita" ovalada. En la parte superior tiene un orificio u ojo de unos $2 \mathrm{~cm}$. por donde se sopla y dos orificios más pequeños un poco más abajo, en forma paralela, que se abren y se cierran con los dedos índices de ambas manos. También se puede hacer de barro. Organológicamente estamos ante un silbato. Es un instrumento de uso básicamente infantil mientras los niños cumplen funciones pastoriles. A veces lo hacen con las mismas manos colocadas una sobre otra formando una cavidad cóncava (una $\mathrm{V}$ invertida).

\section{Sawawa o Maasi}

Según C. Cameron sawawwa es un término genérico equivalente a flauta, aunque en la práctica se trata de un clarinete. Esta confusión se extiende incluso a que se utiliza indistintamente los nombres de sawawa y maasi. Esta situación se da también en otras culturas como sucede con el aulós griego, término que significa flauta, aunque en la práctica era un clarinete doble. El sawawa es un clarinete de unos $20 \mathrm{~cm}$. de largo por $1 \mathrm{~cm}$. de diámetro de tubo abierto en la parte inferior y cerrado en la superior, bien por un nudo natural de la caña de un arbusto espinoso conocido como "siíchi", o hecho con cera negra. La lengüeta se logra con un corte longitudinal sobre el mismo tubo en la misma dirección por donde el tocador lo introduce en la boca a un centímetro del comienzo del tubo, quedando sujeto al mismo cuerpo al otro lado del corte. Puede el ejecutante introducir un cabello atravesado para que levante la lengüeta y pueda vibrar mejor. Algunos ejecutantes llegan a cerrar con la lengua la parte superior del tubo que va en la boca. El número de orificios no es estable. Puede variar entre 3, 4, 5 ó 7 (y hasta sin orificios) a una distancia entre ellos de 1 y $2 \mathrm{~cm}$. Se coloca la mano izquierda en la parte superior y la derecha debajo, utilizando dos o tres dedos de cada mano de acuerdo a la cantidad de orificios.

Una característica muy destacada en la ejecución de los aerófonos goajiros, es la producción de una nota escapada y reiterativa tipo pedal, que parecería que lo hacen dos instrumentos, cuando en 
realidad es uno sólo que se produce al abrir y cerrar el primer agujero con el dedo índice de la mano izquierda. El wayúu conoce este sonido con una función acentual o rítmica como ron-ron y cumple la función de acompañamiento amétrico de la melodía generalmente la nota más baja de la "escala" utilizada.

También entre los guajiros se puede encontrar una flauta (casi ya como una curiosidad) de hueso de fémur de chivo o inclusive de tubo de plástico de unos $25 \mathrm{~cm}$. de largo y de 0,50 cm. de diámetro con canal de insuflación a veces hecho con el labio inferior y otra con un semitapón de madera que conduce el aire a chocar contra el borde de un orificio en la parte superior. Lleva tres orificios en la parte inferior del tubo. Este instrumento se lo conoce con el nombre de maasi y no lleva la nota escapada.
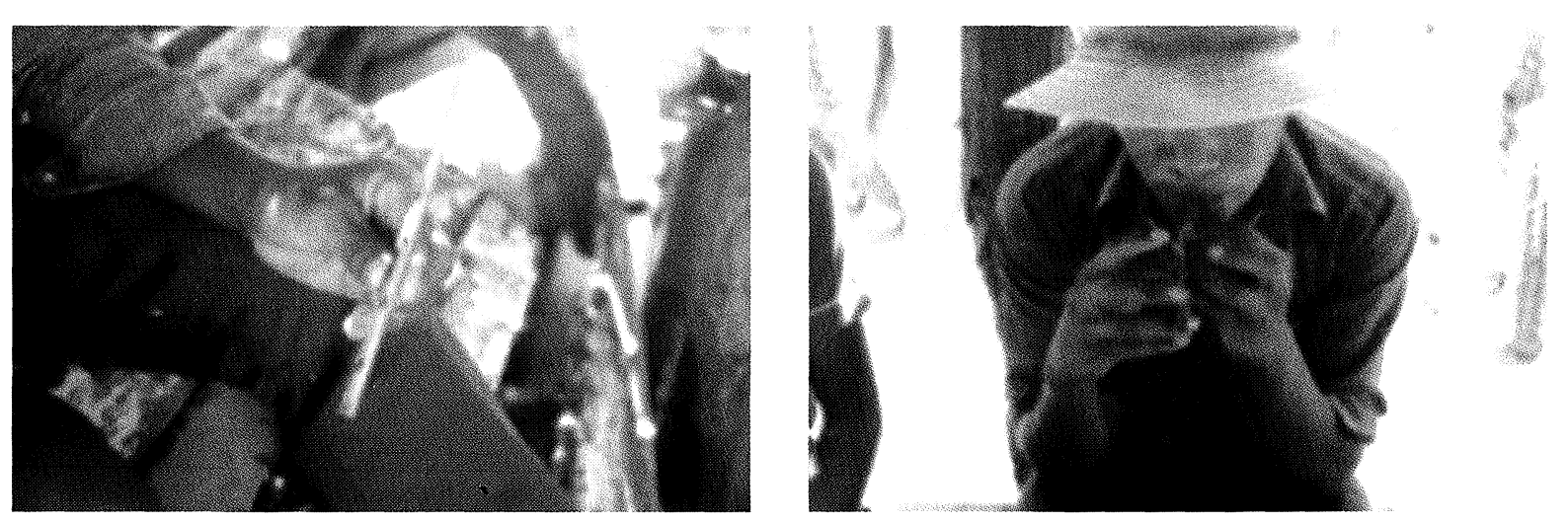

\section{Wootoroyoi, Tootoy o tootoroyoy}

Es el aerófono más importante en la cultura guajira aunque en franco proceso de extinción. Es usado para entretener las largas horas de soledad del pastor. Es un instrumento con tres secciones claramente definidas: una caña o boquilla de unos $10 \mathrm{~cm}$. y 1 de diámetro, con una lengüeta invertida de abajo hacia arriba cortada sobre el mismo tubo que generalmente se separa con un pelo o crin de animal para que levante la lengüeta y vibre mejor. El orificio superior de esta caña se tapa con cera negra, un pedazo de madera, o con la misma lengua. El cuerpo central del instrumento es también de caña, de unos $50 \mathrm{~cm}$. de largo y unos $2 \mathrm{~cm}$. de diámetro, con cuatro o cinco orificios y una calabaza en forma de campana añadida en la parte inferior del tubo que sirve de caja de resonancia. La caña que se usa para su construcción es de sawawa o de siischi.

Su sonido nasalizado es muy característico. Además es mucho más grave que lo que daría por la longitud del tubo, y es que, la lengüeta invertida produce ese fenómeno acústico tan importante. El patrón de la altura fija del instrumento, el constructor lo saca de oído de acuerdo a la tradición wayúu, así como coloca los orificios sin medidas exactas. Esto hace que el diapasón no es el mismo entre todos los modelos, ya que la construcción se hace en forma experimental, por lo cual el resultado es una simple aproximación al patrón. 
La primera notificación que tenemos de este instrumento se lo debemos al Dr. Adolfo Ernst el año 1870 al referirse a un ejemplar que trae de la Guajira Anton Göring.

El wootoroyoi produce también la nota escapada.
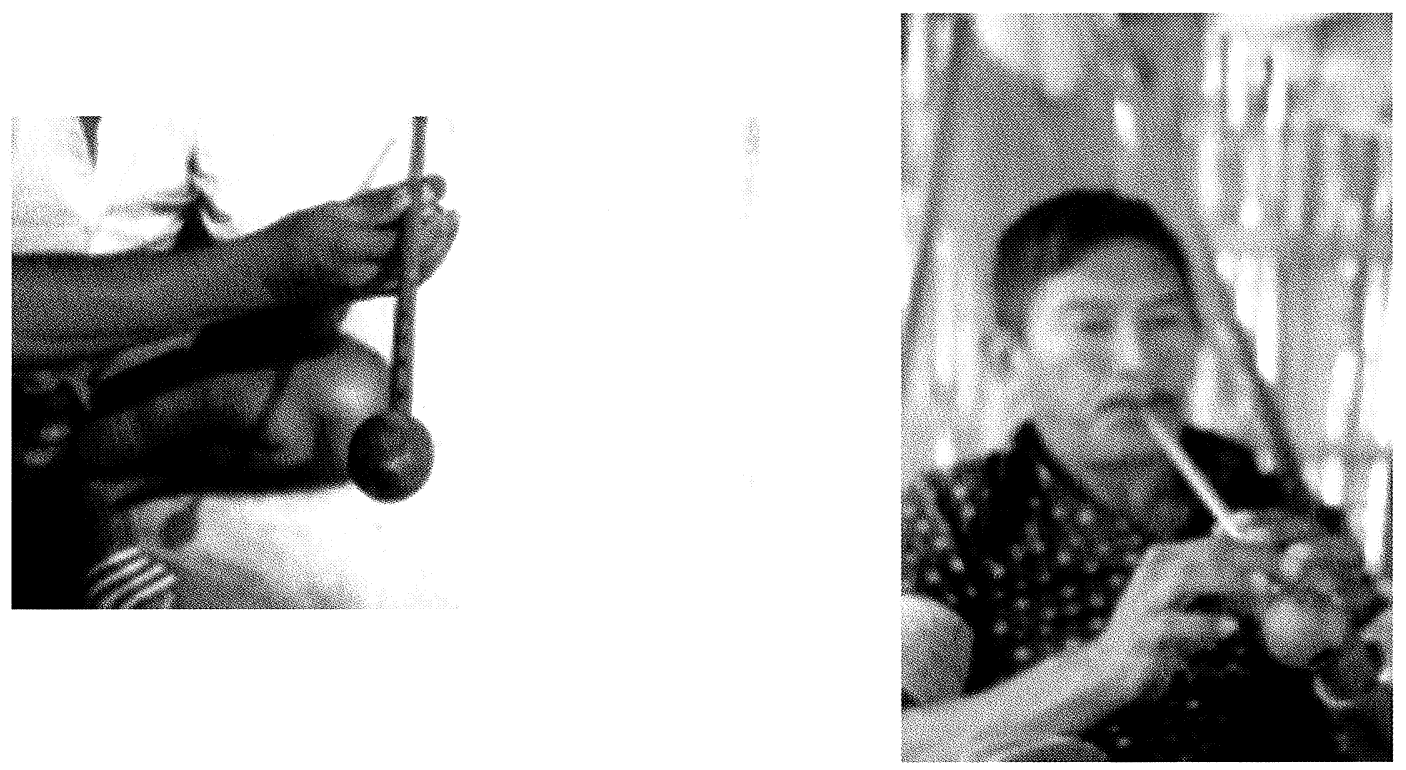

Taliray

El taliray es una de las curiosidades organológicas más interesantes. Es el único cordófono que la etnomusicología latinoamericana reconoce como existente en América antes de la llegada del europeo. Se trata de un arco de madera unidos los dos extremos por un hilo vegetal, cerda o crin de caballo, u otro animal, de unos $25 \mathrm{~cm}$. de largo, cuya cuerda se frota con una vara o con otro arco de características similares. El ejecutante coloca un extremo del instrumento en la boca que le sirve de caja de resonancia y produce los sonidos colocando el dedo índice de la mano izquierda sobre la cuerda para producir un número reducido de sonidos con muy baja intensidad. Evidentemente, estamos ante un instrumento intimista y personalista. Hoy está en franca situación de extinción. De hecho, el año 2003 en que me acompañó un grupo de jóvenes indígenas universitarios de la Universidad del Zulia al evento América Suena organizado en el mes de agosto en el Auditorio Nacional y Museo de Antropología en la ciudad de México, al comentarles sobre este instrumento, ellos no lo conocían.

Este instrumento es conocido en la organología mundial como arco musical. Hay también testimonios de él desde la Cueva de los Dos Hermanos en Francia en tiempos prehistóricos, hasta grupos étnicos actuales. Es otra de las curiosidades organológicas por su amplia dispersión, algo similar a lo que señalamos en el caso del birimbao. 

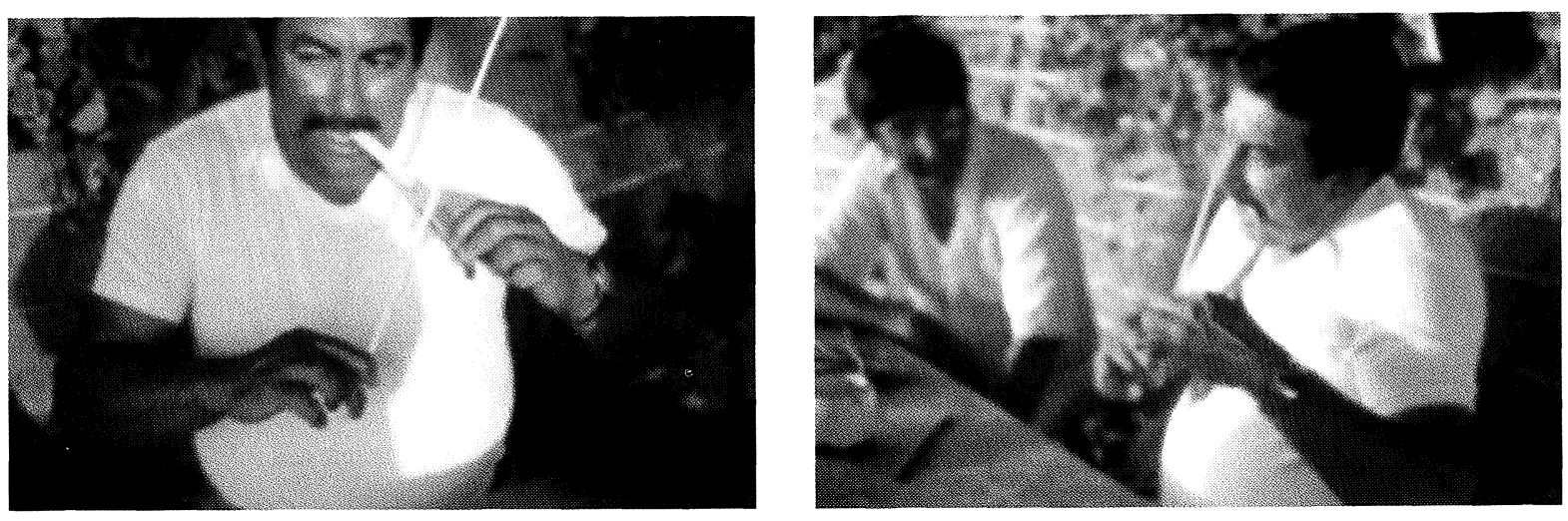

\section{Las danzas}

Los bailes y danzas las realizan los wayúu para celebrar la cosecha, marcar y castrar animales, blanqueo, un buen negocio o simplemente por entretenimiento.

En general se mezcla el concepto de danza y fiesta. Y es que estas danzas se hacen en el marco de una celebración, por eso se habla indistintamente de danza o fiesta, por ejemplo, de la chicha maya o de la cabrita. Una de las demostraciones de poder o prestigio en el guajiro es el poder dar estas fiestas, pues tienen la creencia que todo lo que se gaste en dar de comer, se retribuirá en beneficios. Estas fiestas generalmente las dan guajiros con muchos animales, pues implica un gasto muy alto. El concepto de danza o baile en el guajiro no está relacionado con rituales religiosos o de creencias, pues como ya hemos señalado, el guajiro no tiene un marco litúrgico establecido.

El baile guajiro más conocido es La Chicha maira o maya, "Yonna" o "Ayonaha". Alfredo Jahn es el primero que el año 1927 la califica como "chicha maya". Es un baile de pareja libre con acompañamiento de toques de casha. Probablemente de origen agrario "para celebrar la recolección de la cosecha en noches de luna llena", hoy en cambio se realiza por muy variadas razones, como son para iniciar y terminar la reclusión ("blanqueo") de la joven mujer, matrimonio, nacimiento de un niño, marca de animales, por promesa, cumplimiento de un sueño, un buen negocio etc. Se baila por diferentes razones. Es la danza más popular y conocida también fuera del ámbito guajiro. Se realiza en un espacio redondo al aire libre conocido como el "piouy" previamente acomodado. El varón, ataviado o no con vestimenta de gala, con pies descalzos y siguiendo las órdenes del músico que toca la casha, danzando en rueda y hacia atrás siguiendo las agujas del reloj, con unos gritos convoca a su pareja a que salga a danzar. La mujer con su manta, sonajas colocadas en manojo en sus tobillos y pañolón, descalza como el hombre, se aproxima a la pareja y con pasos elegantes le persigue hasta que con una zancadilla el varón tropieza y cae al piso. El público colocado en rueda aplaude y celebra el momento, a la vez que se sustituye la pareja. A veces la pareja se cambia simplemente por cansancio. Ese revoloteo de la mujer sobre el varón, ha propiciado que algunos autores la califiquen de una danza amorosa o danza de las tórtolas.

Algunos autores como Turrado Moreno hablan de un coro especializado que canta mientras se baila. En nuestros viajes nunca vimos que se cantase en los bailes de la yonna. 
El baile se puede realizar a cualquier hora, pero nosotros lo vimos siempre a la caída de la tarde y primeras horas de la noche.

El baile de la cabrita, "kaulayawa", es otro de los bailes guajiros. Se lleva a efecto cuando llegan las lluvias. Se hace también en la tarde-noche. Se alistan en dos hileras los bailadores alternándose hombres y mujeres. A las órdenes de la casha los cabecillas de cada una de las hileras se acercan y comienzan un diálogo improvisado con preguntas como ¿de dónde viene?, ¿cómo está?, etc. Ante la pronunciación de algún nombre de animal, la fila que corresponde al que la dijo, imita el comportamiento de ese animal (tigre, "samuro"...).

Pineda Giraldo describe así el baile de la cabrita:

Un grupo de indios cogidos de la mano forman un círculo que finge ser el corral donde se guardan las cabras por la noche. Fuera del corral están los machos cabríos representados por otros indios que, a la vista de las cabras encerradas en el corral, dan vueltas alrededor y hacen intentos sucesivos de entrar. Los indios que representan el cerco los rechazan, pero al fin logran saltar dentro uno o dos machos; una vez dentro fingen y toman todas la actitudes del macho cabrío en celo: persiguen las hembras, las huelen, las acosan y, por fin, simulan el acto sexual.

En este caso esta danza o representación teatral de carácter imitativo se hace acompañada por cantos donde con la letra van guiando o señalando lo que tienen que hacer los bailarines o actores. Este baile o fiesta de la cabrita o cabrito, puede realizarse con motivo de la castración o marcaje de ovejas y cabras. Es una de las fiestas de cierto carácter secreto probablemente por las libertades permitidas. Es una de las válvulas de escape de esta sociedad donde los excesos están permitidos para esa circunstancia, cosa que no haría a la luz del día y en el acontecer social ordinario. El kaáulayawaa es un momento de permisibilidad mágica ${ }^{13}$.
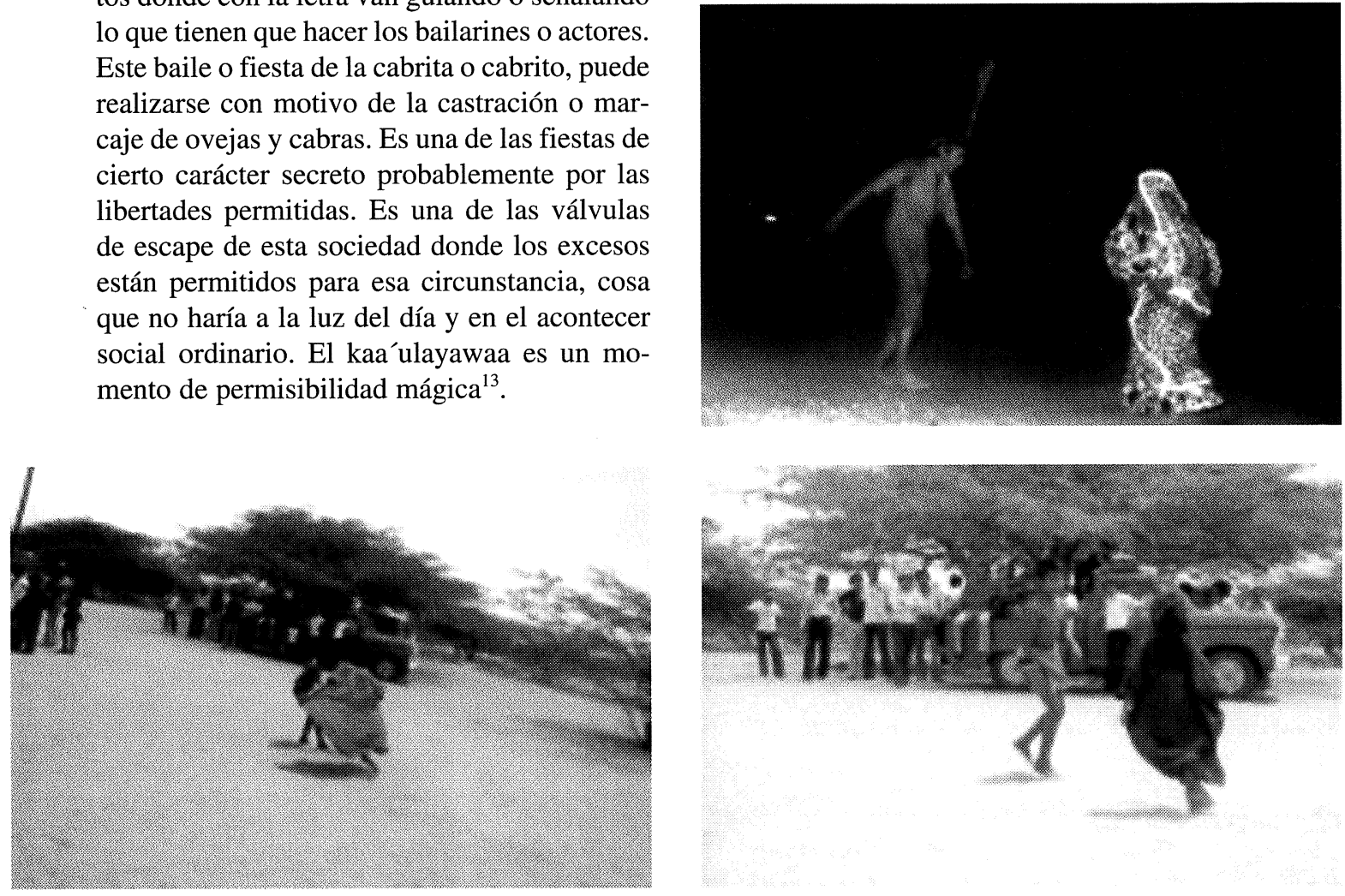

13. PINEDA G., Roberto, 1947: 129. 
El baile del baño se hace también al compás de la casha. Se trata de un baile que se hace cuando la muchacha que estuvo recluida (blanqueo) después de su primera menstruación, aprendiendo las cosas que una mujer guajira debe saber. Comienza el baile y a eso de la media noche sale la muchacha ("majayura") y en una especie de biombo se baña la homenajeada.

El baile de la mosca o "jayamüleryá". Es similar al baile de la chicha maya, pero en vez de participar parejas sueltas, lo hacen hasta unos veinte participantes ataviados con vestimenta de gala.

Hay otros bailes como el de la representación de la serpiente, animal que tiene un valor mágico para los guajiros. Este tipo de variantes de bailes y danzas habría que enmarcarlas más como representaciones teatrales. En estas representaciones los textos son improvisados, donde se mezclan las ocurrencias del momento vivido y las tradiciones mágicas; por eso no hay nada estereotipado, fijo.

\section{Investigaciones etnomusicológicas}

Las primeras referencias sobre música guajira en forma científica las hace el Dr. Adolfo Ernest $(* 1832 ; \dagger 1899)$ en el siglo XIX. En cambio, las primeras grabaciones registradas se las debemos al humanista Juan Liscano en forma privada hacia el año 1940, en una feria realizada en Barquisimeto en un viejo equipo de disco. Estas grabaciones, con otras que el mismo estudioso hace en la zona de Barlovento, pasan a ser la base del repositorio documental al momento de fundar el Servicio de Investigaciones Folklóricas Nacionales en el Ministerio de Educación el año 1945 y que terminará siendo más adelante el Instituto Nacional de Folklore.

El profesor Agustín Pérez Piñango desde el Museo de Ciencias Naturales de Maracaibo hace investigaciones en la Guajira y la Comisión Indigenista le publicó un disco con comentarios de Francisco Carreño. El año 1957 los esposos Luis Felipe Ramón Rivera e Isabel Aretz, con Abilio Reyes, grabaron también en Sinamaica y Laguna del Pájaro, relativamente cercano a la ciudad de Maracaibo un subgrupo conocido como paraujanos. No llegaron a entrar en la Península Guajira.

El año 1970 Catherine Cameron bajo la dirección del Dr. Helmuth Fuchs viajó a La Guajira produciendo un informe que citamos en el presente trabajo.

El año 1974 hicimos nuestro primer viaje a La Guajira en el marco de la investigación en la Sierra Nevada de Santa Marta, Plan Multinacional Colombia de la Organización de Estados Americanos, el Instituto Interamericano de Etnomusicología y Folklore y "Colcultura" (organismo oficial colombiano de cultura para el momento) por parte del gobierno colombiano. En esa oportunidad, además de estar con los indígenas Kogí y Arahuacos en las altas serranías, recorrimos detalladamente toda la zona baja de la Sierra de Santa Marta en la que se incluyó la Baja Guajira en la parte colombiana. Hicimos las primeras grabaciones con equipos técnicos de altísima calidad (Nagra IV y Nagra $\mathrm{SN})$ y con criterios metodológicos etnomusicológicos estrictos.

El año 1976 en los meses de agosto-septiembre volvimos a La Guajira coordinando un grupo de becarios del Instituto Interamericano de Etnomusicología y Folklore. Recorrimos La Baja y Alta Guajira en la parte venezolana, desde Sinamaica y Los Filuos hasta Castilletes. Participaron en este proyecto Pastor Ponce, Ylda Laforest, Napoleón Valverde y el indígena Luis Barroso contratado in 
situ como guía. Grabamos nueve cintas de $600 \mathrm{ft}$ y nueve de $1200 \mathrm{ft}$, así como se hicieron un número significativo de fotos en blanco y negro, a color, diapositivas y películas $\mathrm{S}^{14}$. Además trajimos ejemplares de los instrumentos musicales para el instituto, porque en aquel momento había el proyecto de llevar a cabo un museo de instrumentos musicales de América Latina. En algunos casos fue difícil ya conseguir informantes fiables como sucedió con la búsqueda de un buen ejecutante de "wotoroyoi" que tuvimos que introducirnos en el Cerro de la Teta en el territorio colombiano. Todos estos materiales pasaron a los fondos del Instituto Interamericano de Etnomusicología y Folklore, los cuales a partir del año 1986 se funden con los fondos del Instituto Nacional de Folklore y el Museo del Folklore en el Centro de Cultura Popular y Tradicional, CCPYT. Posteriormente se le cambiará de nuevo la denominación de la institución por Fundación de Etnomusicología Folklore hasta el día de hoy. Curiosamente Isabel Aretz, en su libro La Música de los Aborígenes de Venezuela, ni siquiera cita las investigaciones del año 1974 y 1976 cuando precisamente se hacen mientras ella se desempeñaba como directora del Inidef.

En el mes de julio del año 1982, el Instituto Interamericano de Etnomusicología y Folklore realiza en la Guajira otra práctica de investigación de campo con los alumnos Rose Marie Reis García, Jorge Zambrabo Miranda, Lizardo Domínguez Méndez, Dinara H. Pessoa, María Fornaro Bardolli, Carlos Ríos, Fabio Meza Ruiz, Alfonso Arrivillaga Cortés, Jorge Pocaterra Apüshana bajo la coordinación de Igor Colima y con la asistencia de Elizabeth Monascal y Elpidio González. Producto de este nuevo estudio es la publicación Contribuciones al estudio de la Etnomúsica y Cultura Wayúu de Rose Marie Reis García, Dinara H. Pessoa y Fabio Meza Ruiz. Cada uno de los alumnos hace su propia monografía, aunque solamente fueron publicadas posteriormente las señaladas.

Hay que señalar que en los últimos años las investigaciones etnomusicológicas en el país han sufrido un grave deterioro. Las instituciones oficiales que hasta mediados de los años ochenta del siglo pasado estuvieron tan activas y jugaron un papel tan importante a nivel latinoamericano, por la inestabilidad política general del país, fueron también objeto de muchos cambios de sede, fusiones de instituciones, incorporación y desincorporación de personal etc. lo que llevó a una desmejora ostensible. Poco a poco, el trabajo de investigación de campo fue disminuyendo hasta el punto que durante los últimos años han sido muy pocos los trabajos realizados.

En el caso de la Guajira, en el joven departamento de música de la Universidad Cecilio Acosta en Maracaibo, hemos podido constatar el año pasado en la participación en un encuentro de investigación organizado por la institución, que se están haciendo algunos trabajos a cargo de profesores y de tesistas que esperamos se publiquen.

\section{Bibliohemerografía}

Antropólogos, juristas, lingüistas, ingenieros, geógrafos, naturalistas, exploradores, informes de misiones gubernamentales, etnomusicólogos..., se han detenido en una amplia bibliohemerografía

14. El detalle sobre los trabajos realizados se encuentra en los informes que se entregaron a la institución. 
relacionada con la cultura wayúu. Aquí solamente vamos a destacar la más cercana a la orientación etnomusicológica del trabajo.

Las fotos utilizadas en el presente trabajo son cortesía de la Fundación de Etnomusicología y Folklore, Fundef.

ARETZ Isabel. Instrumentos musicales de Venezuela. Cumaná: Editorial Universitaria de Oriente, 1967: 317pp.

CAMERON, Catherine. "Descripción y análisis de la música de los indios guajiros en Venezuela". Kasmera. Vol. 4, n 4, Maracaibo: Universidad del Zulia, 1973: 329-409.

Catálogo de Misiones INIDEF - OEA 1973-1983. Caracas: Centro para las Culturas Populares y Tradicionales, CCPYT, s/f.

DOMÍNGUEZ, Lizardo. La música en el contexto sociocultural de los Wayúu. 1982.

ERNST, Adolfo. "La posición etnográfica de los indios gujiros". Boletín indigenista venezolano. T. VII. Caracas: Comisión Indigenista, 1959: 45-69.

KUETHE, Allan. "The pacification campaign on the Riohacha frontier, 1722-1779". Hispanic American Historical Review 50, 1970: 467 - 481.

LAFFER, Luis. Folklore de Venezuela, vol 4, 1971 (Discos de pasta).

JAHN, Alfredo. Los aborígenes del occidente de Venezuela. Caracas: Monte Ávila Editores, 1973: 212pp.

MATOS ROMERO, Manuel. Derecho civil y penal guajiro. El "pupchipu" o abogado guajiro. Maracaibo: Tipografía Unión, 1975: 147 pp.

—. Juítatay juyá (Ojalá lloviera). La Guajira su importancia. Caracas: Empresa el Cojo C. A., 1971: 441pp.

—. La Guajira su importancia. Caracas: Empresas El Cojo, 1971: 450pp.

—. La sedienta Guajira. Maracaibo: Dirección de Cultura de la Universidad del Zulia, 1975: 351pp.

PEÑíN, José. "Misión Colombia 1974". Revista Inidef. № 1. Caracas: Instituto Interamericano de Etnomusicología y Folklore - Conac, 1975: 123-124.

PERRIN, Michel. "Introducción a la literatura oral de los indios Guajiros". Economía y Ciencias Sociales. XII. Caracas: Facultad de Ciencias Económicas y Sociales, Universidad Central de Venezuela, julio-septiembre, 1970: 5-20.

—. El camino de los indios muertos: mitos y símbolos guajiros. Caracas: Monte Ávila Editores, 1992:271pp.

PINEDA GIRALDO, Roberto. “Aspectos de la magia en la Guajira”. Revista del Instituto Etnológico Nacional. III. Bogotá: Instituto Etnológico Nacional, 1947: 1-164.

POLANCO, José Antonio. "Noticias guajiras". Boletín Indigenista Venezolano. Año II, T. II. Caracas, 1954: $55-60$.

—. "Noticias guajiras". Boletín Indigenista Venezolano. Año VI, T. VI. Caracas, 1958: 197-204.

—. "Noticias guajiras". Boletín Indigenista Venezolano. Año VIII, T. VIII. Caracas, 1963: 103-114.

RAMÓN Y RIVERA, Luis Felipe. "Consideraciones sobre un instrumento y música de los indios guajiros". Acta Venezolana, T. II, n 14. Caracas, 1946-1947: 1-4.

SALER, Benson. "Los Wayúu". Los Aborígenes de Venezuela. T. III. Caracas: Fundación La Salle de Ciencias Naturales, 1987: 29-145.

TURRADO MORENO, Ángel. Cómo son los Guajiros. Tercera Conferencia Interamericana de Agricultura. Caracas: Tipografía el Compás, 1950: 63-66.

VARIOS AUTORES. Los aborígenes de Venezuela. Caracas: Fundación La Salle de Ciencias Naturales. Instituto Caribe de Antropología y Sociología. Monte Ávila Editores, C. A., Vol. III, 1988: 25-147.

WATSON, Lawrence G. "Guajiro social structure: a reexamination". Antropologica 20, 1967: 3-36.

- "Guajiro Personality and urbanization". Latin American Center. Los Angeles: University of California, 1968. 
WILBERT, Johannes. "Literatura oral y creencias de los indios Guajiros". Caracas: Memoria de la Sociedad de Ciencias Naturales La Salle, XXII, 1962: 103-115.

-. "Goajiro kinship and eiruku cycle. The social anthropology of Latin America: essays in honor of Ralph Leon Beals. Los Angeles: University of California, Latin American Center, 1970: 306-357.

-. Survivors of Eldorado: four Indian cultures of South America. Praeger University Series, Antropology. New York: Praeger Publishers, 1972. 